\title{
Long-term implications of traditional forest regulation methods applied to Maritime pine (Pinus pinaster Ait.) forests in central Spain: a century of management plans
}

\author{
Bravo $F^{(1-2)}$, Osorio LF ${ }^{(1-4)}$, Pando $V^{(2-3)}$, Del Peso $C^{(1-2)}$ \\ Pinus pinaster stands in the northern Iberian range (Spain) have been under \\ forest management plans for more than a century. The main goals have been \\ sustainable yield and conservation and enhancement of forest conditions. In \\ the study area, forest management plan implementation started to be effec- \\ tive in the late $19^{\text {th }}$ and early $20^{\text {th }}$ centuries and the plans have been evaluated \\ every ten years. In these forests, a permanent forest compartment method has \\ been applied as the management system. Different regeneration methods have \\ been applied (uniform shelterwood and clear cutting in Soria, selective and \\ uniform shelterwood and continuous cover forestry in Teruel). To analyse the \\ evolution of each forest group, five management indicators have been tested \\ in this study: number of merchantable trees, standing volume, resin produc- \\ tion, allowable yield, and harvested volume. Forest situation improvement and \\ maintenance of forest integrity are not only a consequence of the actions \\ planed by foresters, they are also influenced by socio-economic transforma- \\ tions that have occurred during the last century such as the weakness of the \\ resin market, decreasing demand for fire wood, restriction of pasture activi- \\ ties, and increasing recreation use.
}

Keywords: Forest regulation, Indicators, Standing volume, Harvest volume, Pinus pinaster Ait.

\section{Introduction}

Operational forestry is limited by social, ecological, economic, and legal constraints. In Spain, as in many countries around the world, forestry science originated in the Central Europe of the late eighteenth century, when the main concern was wood/fuel supply and game protection. As is well known, forestry possesses a long-term nature

(1) Dept. de Producción Vegetal y Recursos Forestales, E.T.S. de Ingenierías Agrarias, Universidad de Valladolid, Avda. de Madrid, 44 E-34004 Palencia (Spain); (2) Sustainable Forest Management Research Institute UVa-INIA (Spain); (3) Departamento de Estadística e Investigación Operativa. Universidad de Valladolid (Spain); (4) Universidad Nacional de Colombia, Medellín (Colombia)

@ Felipe Bravo (fbravo@pvs.uva.es)

Received: Nov 03, 2009 - Accepted: Dec 18, 2009

Citation: Bravo F, Osorio LF, Pando V, Del Peso C, 2010. Long-term implications of traditional forest regulation methods applied to Maritime pine (Pinus pinaster Ait.) forests in central Spain: a century of management plans. iForest 3: 33-38 [online: 2010-03-02] URL: http://www.sisef.it/iforest/doi.php? doi $=10.3832 /$ ifor0526-003 arising from long tree life-spans that, in temperate zones, can cover several human generations. In this context, historical analysis of forest organization can be used to develop criteria and indicators to evaluate the management processes in different forest areas effectively. In spite of its limitations, this kind of retrospective studies is acknowledged in adaptive management as a source of valuable information for shaping forest management practice. Historical studies are an attempt to demonstrate changes in management indicators, including the number of trees per hectare or wood volume by using certain variables or parameters. By doing this, we can study the long-term sustainability of the management methods used. As forest management has a multidimensional impact on forests and forest communities, the best strategy in analysing management effects is to include the largest possible number of indicators provided by the forests management plans. Over the last decade, different analyses have been performed on changes in organized forests to observe the response to various management models (Charnley et al. 2008). The greatest difficulties in carrying out these types of studies are the limited amount of reliable document sources (mainly management plans), because document structure changes as legal regula- tions evolve. The numerical data are therefore difficult to compare, and only general trends can be defined. The limited span of this kind of studies is not strange, considering the difficulty of obtaining long-term, reliable, comparable data sets. In southern Europe, Spain is the only country where forest management plans have been applied effectively and indicators reflecting the silviculture applied in the past can be analysed thoroughly. It is important to emphasize that, in most cases, the organization of Spanish forests has not included economic variables in forest management as clearly stated objectives. Revenue and expense information is rarely included, and it is very difficult to find the information needed to perform a proper economic evaluation. Although retrospective evaluations of forest management results are generally performed on individual forests, we can gain insight on a landscape approach over a long-term period by studying operational forestry documents.

Forest model, permanent plot, and temporary plot approaches have been defined as useful tools for evaluating forest management practices. All these methods have different limitations (mainly spatial and temporal) and conclusions drawn from such studies can be limited by the monitoring design. As usual in forestry research, one of the main concerns is the limited time span analysed and the limited spatial scope of the study.

Studies on Pinus pinaster management effects are scarce despite its being one of the most representative conifers in the Mediterranean basin, where it is widely distributed, occupying around four million ha (Ribeiro et al. 2001). The species grows in a wide range of ecological conditions: from pure Mediterranean climate conditions such as those found in eastern Spain, Italy, and southern France, to the continental climate of inland Spain or the Atlantic climate of western France, Portugal, and north-western Spain.

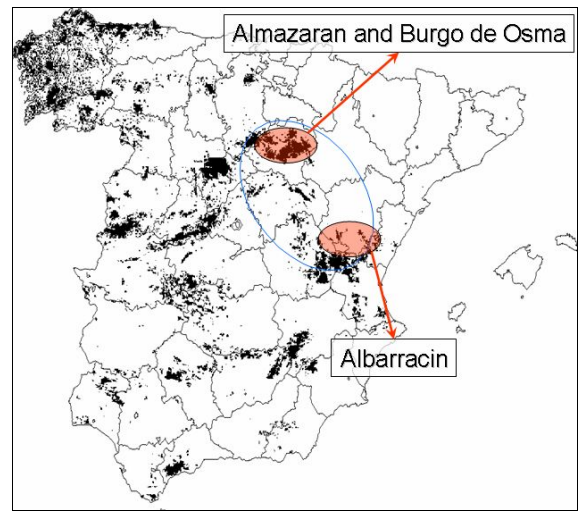

Fig. 1 - Location of the study area (southern Iberian Range). 
Existing studies have analysed silviculture by developing yield and growth models (Bravo-Oviedo et al. 2006 and BravoOviedo et al. 2007, Pascual et al. 2007), regeneration (Herrero et al. 2007), genetics (Vendramin et al. 1998, González-Martínez et al. 2001, De-Lucas et al. 2008, De-Lucas et al. 2009), and economics (Bravo et al. 2008). However, there are no studies on practical long-term forestry effects in Mediterranean Maritime pine forests.

Effective forestry application requires understanding the long-term effects of different management strategies. Although an extensive permanent plot network can be the most useful (and the most expensive) way to obtain responses to some questions on longterm effects of silviculture by monitoring actual forestry actions, valuable information useful in guiding forest management can be obtained. In this study, our main objective was to evaluate the long-term implications of traditional forest management practices upon forest sustainability of Maritime pine (Pinus pinaster Ait.) stands in the Southern Iberian Range (Central Spain). This analysis was performed on three groups of forests that have similar characteristics, through five different management indicators including the number of merchantable trees, standing volume, resin production, and allowable and actual harvest. The proposed methodology can serve as a model for performing similar studies in other forest ecosystems under an adaptive management approach.

\section{Materials and methods}

\section{General forest characteristics}

The organized Pinus pinaster forests studied are concentrated into three groups, two in the province of Soria (Almazán and Burgo de Osma forests) and one in the province of Teruel (Albarracín forest) in the southern Iberian Range in Central Spain (Fig. 1). Covering an area of 17171 hectares, these three groups were first organized in 1899 , 1903, and 1907 (Tab. 1). Management revisions are generally performed every ten years, but in some cases they have not been carried out because of situations of public order (i.e., the Spanish civil war) or budget restrictions. Teruel forests have only been evaluated since 1934 due to the loss of the oldest documents on most of its forests. All of these forests are organized using the permanent forest compartment method as described by Davis et al. (2001). Regeneration methods for the forests in Soria have shifted from shelterwood (in which the main activity was resin tapping) to seed tree harvest (where the main objective has shifted to wood production). In Teruel forests, the regeneration method has shifted from a selection system to shelterwood and, finally, to high grading, where the priorities are recre-

Tab. 1 - General characteristics of forests: province of Soria and Teruel.

\begin{tabular}{|c|c|c|c|c|c|c|c|}
\hline Group & $\begin{array}{l}\text { Forests } \\
\text { number }\end{array}$ & Name & Municipality & $\begin{array}{r}\text { Area } \\
\text { (ha) }\end{array}$ & $\begin{array}{l}\text { Organiza- } \\
\text { tion Year }\end{array}$ & $\begin{array}{c}\text { Number of } \\
\text { effective } \\
\text { evaluations }\end{array}$ & $\begin{array}{c}\text { Rotation } \\
\text { age }\end{array}$ \\
\hline \multirow[t]{4}{*}{ Almazán } & 64 & $\begin{array}{l}\text { Pinar de } \\
\text { Matamala }\end{array}$ & Matamala & 1615.00 & 1899 & 9 & 80 \\
\hline & 65 & $\begin{array}{l}\text { Pinar de } \\
\text { Matute }\end{array}$ & Matamala & 1114.34 & 1899 & 9 & 80 \\
\hline & 186 & $\begin{array}{l}\text { Pinar y } \\
\text { Marojal }\end{array}$ & Tardelcuende & 629.33 & 1899 & 9 & 80 \\
\hline & 185 & $\begin{array}{l}\text { Manadizo y } \\
\text { San Gregorio }\end{array}$ & Tardelcuende & 2641.95 & 1899 & 9 & 80 \\
\hline \multirow[t]{4}{*}{$\begin{array}{l}\text { Burgo de } \\
\text { Osma }\end{array}$} & 85 & $\begin{array}{l}\text { Pinar de } \\
\text { Fuenterrey }\end{array}$ & $\begin{array}{l}\text { Quintana de } \\
\text { Gormaz }\end{array}$ & 1427.00 & 1903 & 7 & 80 \\
\hline & 103 & $\begin{array}{l}\text { Pinar de } \\
\text { Valdenebro }\end{array}$ & Valdenebro & 1027.00 & 1903 & 7 & 80 \\
\hline & 55 & $\begin{array}{l}\text { Pinar de } \\
\text { Bayubas }\end{array}$ & Bayubas & 1490.85 & 1903 & 7 & 80 \\
\hline & 57 & $\begin{array}{l}\text { La Mata y } \\
\text { Pinarejo }\end{array}$ & $\begin{array}{l}\text { Berlanga de } \\
\text { Duero }\end{array}$ & 464.37 & 1903 & 7 & 80 \\
\hline \multirow[t]{5}{*}{ Albarracín } & 4 & $\begin{array}{l}\text { Dehesas } \\
\text { Nuevas de } \\
\text { Bezas }\end{array}$ & Albarracín & 535.00 & 1907 & 4 & 120 \\
\hline & 6 & $\begin{array}{l}\text { Muela } \\
\text { Mediana }\end{array}$ & $\begin{array}{l}\text { Gea } \\
\text { Albarracín }\end{array}$ & 2198.20 & 1907 & 4 & 120 \\
\hline & 8 & $\begin{array}{l}\text { Patio Arriba } \\
\text { Rey Don } \\
\text { Jaime }\end{array}$ & Albarracín & 1012.00 & 1907 & 4 & 120 \\
\hline & 7 & Ortezuelo & $\begin{array}{l}\text { Gea } \\
\text { Albarracín }\end{array}$ & 1495.00 & 1907 & 4 & 120 \\
\hline & 14 & El Pinar & Bezas & 1521.00 & 1907 & 4 & 120 \\
\hline
\end{tabular}

ational use and fire prevention.

To provide insight on long-term forest management impact, a multidimensional approach based on five indicators was used: the number of merchantable trees, defined as the number of trees with a diameter at breast height (DBH) greater than or equal to 20 centimetres; standing volume, expressed in cubic meters per hectare; resin production, in kilograms of resin per tree; and both allowable and actual harvest volumes, expressed in cubic meters per hectare. The main objectives pursued with these organizations throughout the region were to increase standing volumes and perform interventions that would make it possible to improve natural regeneration conditions, while increasing and sustaining incomes for local populations.

\section{Data analysis}

Univariate analysis of variance was performed to test the null hypothesis of equality of mean effects of the various revisions. Multivariate analysis tested the null hypothesis of equal effect of the revisions of interaction between the factors in the three variables (standing volumes and allowable and actual harvest volumes) being studied and the repetition variables (Davis 2002, Quinn \& Keough 2002).

Tab. 2 - Univariate analysis of variance by merchantable trees.

\begin{tabular}{llcccc}
\hline Group & Forest & $\begin{array}{c}\text { Sum of } \\
\text { squares }\end{array}$ & $\begin{array}{c}\text { Degrees of } \\
\text { Freedom }\end{array}$ & $\begin{array}{c}\text { Mean } \\
\text { Square }\end{array}$ & p-value \\
\hline Almazán & Forest & 192795 & 3 & 64273 & 0.005 \\
& Revision & 28510 & 8 & 3563.8 & \\
& Error & 22550 & 24 & 939.6 & \\
\hline Burgo de & Forest & 24529 & 3 & 8176.4 & 0.000 \\
Osma & Revision & 91830 & 6 & 15305.6 & \\
& Error & 13571 & 18 & 753.9 & \\
\hline Albarracín & Forest & 147145.3 & 5 & 25449.1 & 0.037 \\
& Revision & 2347.3 & 3 & 782.4 & \\
& Error & 3230.0 & 15 & 215.3 & \\
\hline
\end{tabular}


Fig. 2 - Change in merchantables trees (showing interval of confidence): (a) group of Almazán, (b) Burgo de Osma and (c) Albarracín.
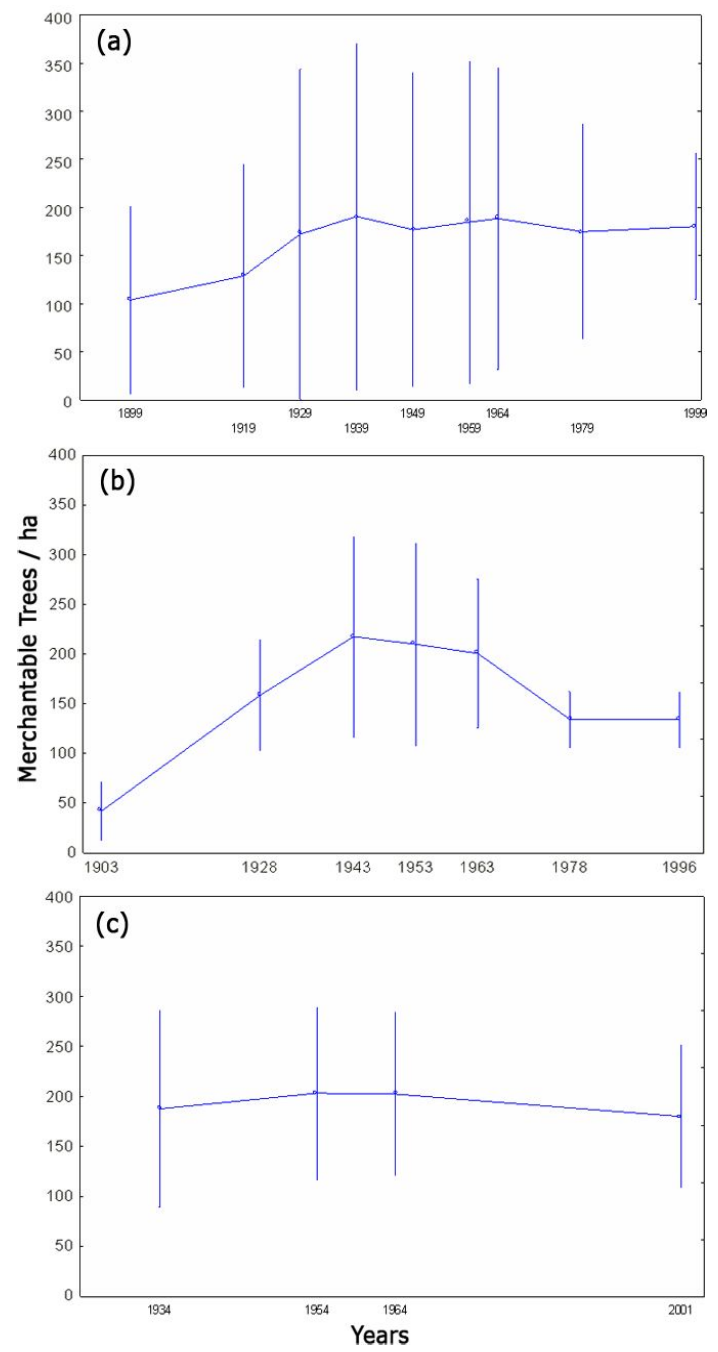

Merchantable trees, standing volume, and resin production

Univariate analysis of variance was used to evaluate the effect that organizations and harvest treatments had on the forests, by observing the changes in certain variables such as the number of merchantable trees (tree/ha), standing volume $\left(\mathrm{m}^{3} / \mathrm{ha}\right)$, and resin production $(\mathrm{kg} / \mathrm{tree})$ in the groups of $\mathrm{Al}$ mazán, Burgo de Osma and Albarracín. In this case, two parameters of variance were performed for the independent variable: the

first reflects the general variability of the measurements between the forests, and the other represents the variability of in-forest measurements that is attributed to the effects of the organizations and successive revisions. These methods are characterized by taking measurements of one single subject over time or under different conditions, requiring fewer subjects than a completely randomized design, and allowing for elimination of residual variation due to the differences among subjects (because the same

Tab. 3 - Univariate analysis of variance by standing volume.

\begin{tabular}{llccrc}
\hline Group & Effect & $\begin{array}{c}\text { Sum of } \\
\text { squares }\end{array}$ & $\begin{array}{c}\text { Degrees of } \\
\text { Freedom }\end{array}$ & $\begin{array}{c}\text { Mean } \\
\text { Square }\end{array}$ & p-value \\
\hline Almazán & Forest & 21766 & 3 & 7255.35 & 0.0001 \\
& Revision & 17010 & 8 & 2126.35 & \\
& Error & 3693 & 24 & 153.91 & \\
\hline Burgo de & Forest & 4123 & 3 & 1374.39 & 0.0001 \\
Osma & Revision & 15758 & 6 & 2626.49 & \\
& Error & 1974 & 18 & 109.71 & \\
\hline Albarracín & Forest & 2947 & 5 & 589.58 & 0.0001 \\
& Revision & 9356 & 3 & 1559.49 & \\
& Error & 1700 & 18 & 94.45 & \\
\hline
\end{tabular}

ones are used). Univariate analyses of variance also make it possible to observe the distribution and difference among the means for each group of forests compared to the variable studied in the medium and long term. Therefore, in the simplest case of studying a factor that acts on several levels, the following model was used for the work (eqn. 1):

$$
Y_{i j}=\mu+\alpha_{i}+\beta_{j}+\epsilon_{i j}
$$

where $\mu$ is the effect of the general mean, $\alpha_{i}$ is the random effect of the forest $i$ with distribution $\mathrm{N}\left(0, \sigma_{\mathrm{M}}^{2}\right), \beta_{\mathrm{j}}$ is the effect of revision $j, \varepsilon_{\mathrm{ij}}$ is the random error for revision $j$ of forest $i$, with distribution $\mathrm{N}\left(0, \sigma^{2}\right)$ in which $\varepsilon_{\mathrm{ij}}$ are independent and equally distributed, $\sigma^{2}$ is the random variance within revisions of a forest and $\sigma^{2 \mathrm{M}}$ is the random variance between forests.

\section{Standing volume and allowable and actual harvest volumes}

The changes in allowable and actual harvest volumes (both expressed as $\mathrm{m}^{3} / \mathrm{ha}$ and year) compared to the standing volume were evaluated on the basis of a multivariate analysis of variance (MANOVA). This made it possible to determine not only whether each of the factors affects the dependent variable separately, but also whether interaction among them modifies that effect (Hair et al. 2006). MANOVA hypotheses compare the equality of vectors for measurements of multiple dependent variables among revisions; MANOVA uses various criteria with which it evaluates multivariate differences among revisions. In this case, the Lambda criterion of Wilks was used, because it is the most commonly used comparison for global MANOVA significance. Multivariate analysis of variance is an extension of ANOVA, in which more than one dependent variable is taken into account, which can be represented using the following formula (eqn. 2).

$$
Y_{i j}=\mu+\alpha_{i}+\beta_{j}+\epsilon_{i j}
$$

in which $Y_{\mathrm{ij}}, \mu, \alpha_{\mathrm{i}}, \beta_{\mathrm{j}}, \varepsilon_{\mathrm{ij}}$ are vectors of $1 \mathrm{R}^{3}$. For example, with:

- $\mathrm{y}^{(\mathrm{k})}{ }_{\mathrm{ij}}=$ value observed for variable $k(k=1$ : standing volumes; $k=2$ : allowed harvest volume; $k=3$ : actual harvest volume) in forest $i$ and revision $j$.

- $\mu^{(\mathrm{k})}=$ effect of the general mean for variable $k$.

- $\alpha^{(\mathrm{k})}{ }_{\mathrm{i}}=$ random effect of forest $i$ on variable $k\left[\alpha^{(\mathrm{k})}{ }_{\mathrm{i}} \sim \mathrm{N}\left(0, \sigma^{2}{ }_{\mathrm{MK}}\right)\right]$.

- $\beta^{\left(\mathrm{k}^{\mathrm{j}}\right.}{ }_{\mathrm{j}}=$ effect of revision $j$ on variable $k$.

- $\varepsilon^{(\mathrm{k})}{ }_{\mathrm{ij}}=$ random error for forest $i$ and revision $\mathrm{j}$ on variable $k$.

It is supposed that for each fixed $\mathrm{k}, \varepsilon^{(\mathrm{k})}{ }_{\mathrm{ij}}$ is independent and equally distributed with the distribution $\mathrm{N}\left(0, \sigma_{\mathrm{k}}^{2}\right)$, in which $\sigma_{\mathrm{k}}^{2}$ is the random variance between revisions of a forest for variable $k$, while $\sigma_{\text {MK }}^{2}$ is the random variance between forests for variable $k$. 
This evaluation was only performed on Almazán and Burgo de Osma groups, because continuous, reliable information was available. Analysis was performed with STATISTICA 5.5 (Statsoft 1995) and SAS/STAT 9.1 (SAS Institute 2006).

\section{Results}

Change in number of merchantable trees

Steady implementation of forest management plans (expressed by number of revisions) has a significant impact on merchantable trees. Revision impact is significant in all forests $(p<0.05)$ but is less evident in Albarracín forests ( $p=0.0376$ - Tab. 2). The number of merchantable trees increases over time in the forests analyzed (Fig. 2). For example, Almazán and Albarracín forests currently show a density of over 150 merchantable trees per hectare, while forest density is 100 trees/ha in Burgo de Osma. In contrast, at the time of organization (late $19^{\text {th }}$ or early $20^{\text {th }}$ centuries), the first two forests had 100 trees/ha, while that of Burgo de Osma had fewer than 50. Two different processes can interact to increase the number of merchantable trees per ha: increasing forest density at stand level and generating a balanced forest age structure at forest level. When regeneration harvests were relatively scarce, the allowable yield was completed by dispersed harvest operation throughout the forests. It is also possible to observe that there are no significant differences in the changes in merchantable trees from applying different regeneration treatments, such as shelterwood and seed trees methods. This may be because operational application of these two treatments shows little difference, because the establishment and final cuttings are grouped into one single intervention in the shelterwood method, after preparatory cuttings with a double objective: increase tree vigour and seed production and allow early seedling establishment. In the three forest groups analysed, there is a trend towards an increase in merchantable trees that verifies the importance of the organizations in the increase in forest density.

\section{Change in standing volume}

Standing volume, like merchantable trees, shows a considerable increase in the period analysed (Tab. 3). The analyses of variance among forests in the same group and within the same forest are highly significant ( $p>0.05$ in all cases). Fig. 3 shows how standing volume gradually increased during the management period in the three groups analysed. During the period studied, standing volume increased from an average of 20 $\mathrm{m}^{3} /$ ha to $80 \mathrm{~m}^{3} /$ ha in the decade of the sixties, stabilizing later at approximately $70 \mathrm{~m}^{3}$. However, the upper limit reaches $140 \mathrm{~m}^{3} / \mathrm{ha}$

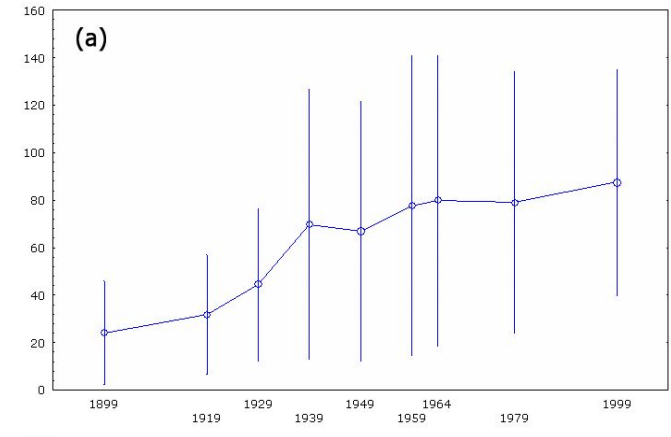

Fig. 3 - Standing volume evolution: (a) group of Almazán, (b) Burgo de Osma and (c) group of Albarracín.
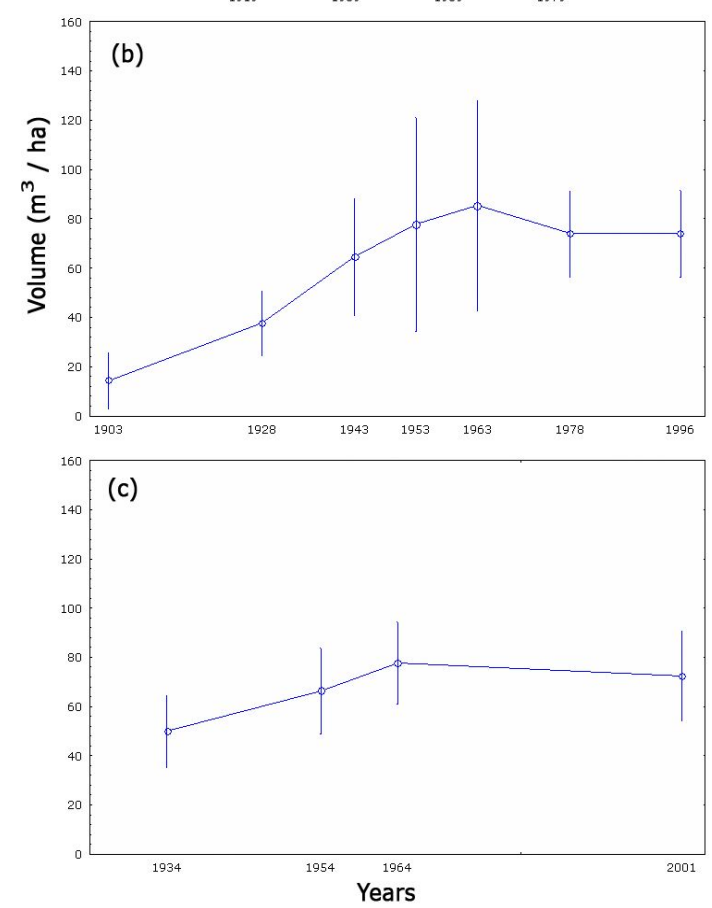

in Soria, while the maximum value is 90 $\mathrm{m}^{3} /$ ha for the forests in Teruel. It is important to mention that a section of the forests in Albarracín has become part of a natural reserve; the handling goal is consequently changing now to conservation in these forests, and the silvicultural treatments applied are therefore changing as well.

Change in pine resin production in the Almazán and Burgo de Osma groups Analysis of changes in resin production is only performed on the Soria groups (Almazán and Burgo de Osma), because ongoing, reliable information is only available for

Tab. 4 - Univariate analysis of variance for resin production.

\begin{tabular}{llcccc}
\hline Group & Effect & $\begin{array}{c}\text { Sum of } \\
\text { squares }\end{array}$ & $\begin{array}{c}\text { Degrees of } \\
\text { Freedom }\end{array}$ & $\begin{array}{c}\text { Mean } \\
\text { Square }\end{array}$ & p-value \\
\hline Almazán & Forest & 2.436 & 3 & 0.812 & 0.006 \\
& Revision & 0.564 & 7 & 0.080 & \\
& Error & 0.426 & 21 & 0.020 & \\
\hline Burgo de & Forest & 0.089 & 3 & 0.029 & 0.000 \\
Osma & Revision & 8.772 & 6 & 1.462 & \\
& Error & 0.587 & 18 & 0.032 & \\
\hline
\end{tabular}

them. The analysis focuses on the changes in resin production per tree throughout the period in which this activity took place. Tab. 4 shows the variance analysis, which has high significance levels. The p-values are far below 0.05 , indicative a high level of variability among the forests and within the forests for each group. Resin production is stable in the Almazán group, while it peaks during the fifties in the Burgo de Osma forest (Fig. 4). In both cases, resin production stabilizes at around $2.5 \mathrm{~kg} /$ tree. After the seventies, production levels dropped due to decreasing tapping profitability and to the introduction of synthetic resins in the market. 
Fig. 4 - Change in resin production: (a) group of Almazán and (b) group of Burgo de Osma.

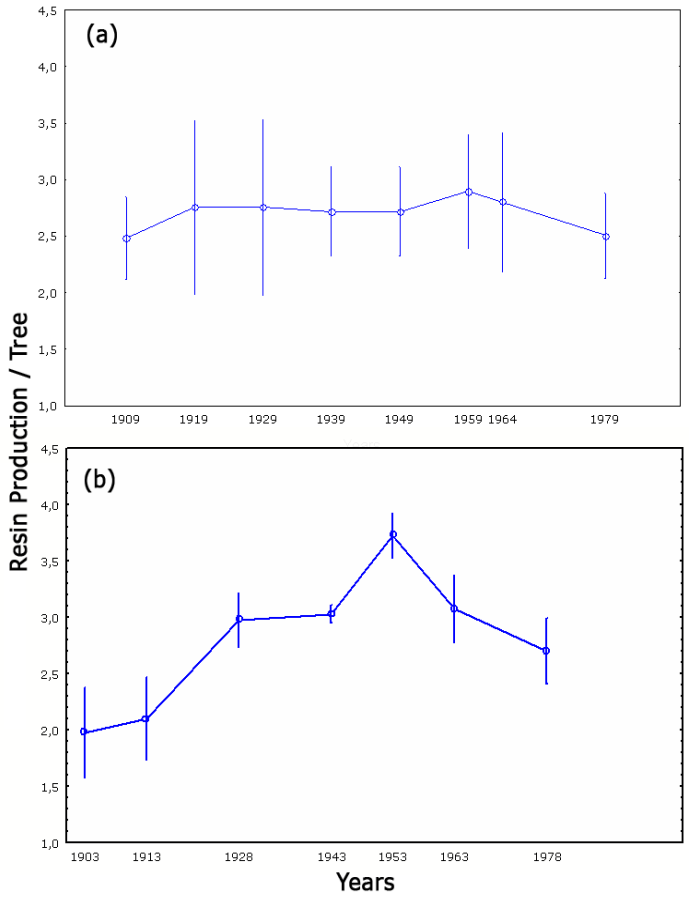

Changes in allowable and actual harvest volumes

There are significant changes in both allowable and actual harvest volumes. In accordance with Wilks' Lambda criteria, as a result of the multiple variant analysis, there is a value of 0.0551 and a statistic of $\mathrm{F}<0.0001$, in which this figure is significant for three reasons: it allows us to interpret that the means among the groups are different, that there are significant variations among plan revisions, and that the changes in each of the variables are not the same (Fig. 5), with the exception of Burgo de Osma's forests during the sixties.

Results from the Burgo de Osma data set, obtained using Wilks' Lambda criteria, are similar to those obtained for the Almazán group, in the sense that they have low Lambda values and the statistic $\mathrm{F}<0.0001$ remains significant. These results suggest that the changes in these three variables do not share a common pattern, despite their increase over time. Standing and harvest (both actual and allowable) volumes increase gradually, but they do not follow the same trend or have the same fluctuations in each period (Fig. 5). This situation simply demonstrates the difficulties that managers face when carrying out organization projects and their constant revisions.

\section{Discussion}

Our study, focused on a wide set of indicators, shows the importance of taking the multidimensionality of forest management effects into account. Timber production, stand density, and non-timber products (resin) have been analysed. Our main finding is that the long-term nature of forest manage- vities.

In the forest areas analysed, stakeholder goals have shifted in the last few decades to a multi-objective approach because of the disappearance of the resin market, the decrease in firewood demand, the restrictions imposed on grazing (which helps the success of regeneration), and the increase in use of forests as recreational areas. The last three are directly connected with migration from rural areas to urban and industrialized areas (which occurred mostly during the sixties and seventies in Spain). In many cases, we can observe a gradual increase in different indicator figures, such as standing volume, the number of merchantable trees, and allowable and actual harvest volumes. However, in some cases the information recorded in the various organization projects has been insufficient to evaluate these forests, even with the most characteristic organization variables. We have only a rough idea of key management activities implemented in the past. In many cases, plan guidelines have been abandoned, either because they did not achieve what was proposed or the main objective simply changed, making it necessary to set up a new organization project. In addition to the aforementioned difficulties, historical evaluations of organizations do not possess reliable economic information. This information is sometimes limited to obtaining economic indicators reflecting the expected profitability of these forests in terms of wood and resin production. However, relevant knowledge can be acquired from different sources, including less-formalized ap- ented to previously-defined goals by gathering information from the past forestry actineed time to adapt to a new situation when goals and procedures change dramatically.

Joint monitoring, with experimentation and , is a core element in management. It should be considered as a key element in management plans because

Fig. 5 - Changes in standing volume, allowable and actual harvest volume in the group and by forests of Almazan (a) and Burgo de Osma (b).
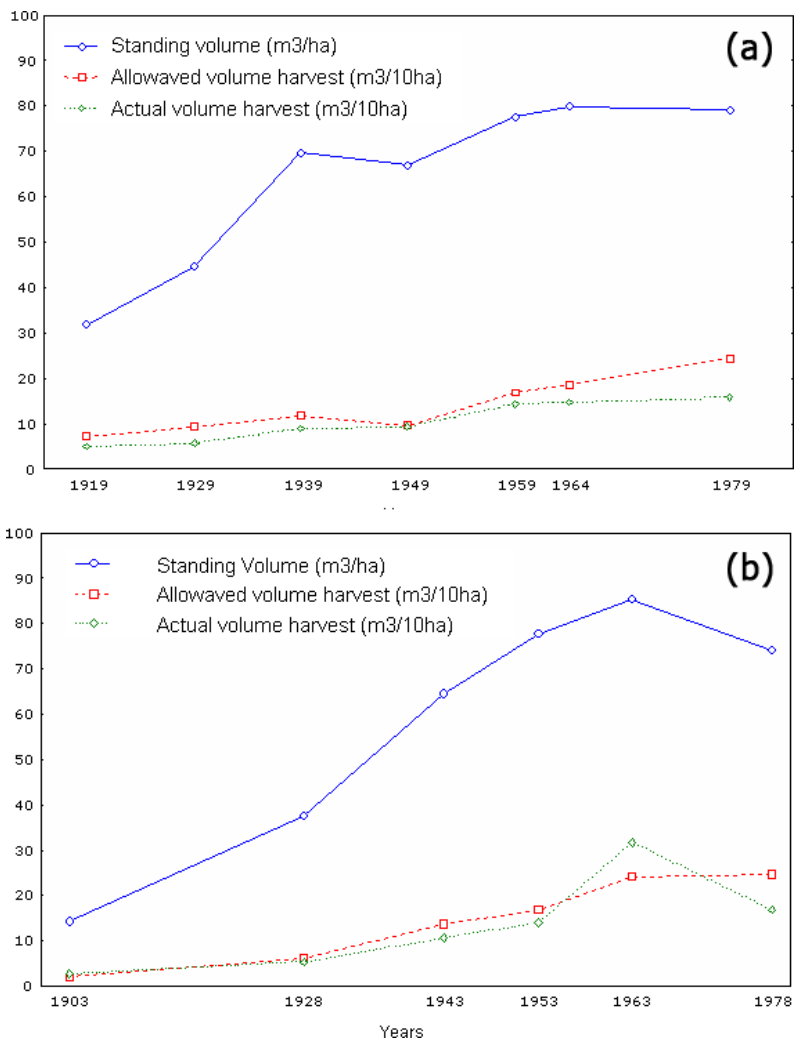
proaches (Davis et al. 2001, Lindenmayer \& Franklin 2002) that complement information from well-designed experiments and monitoring programs.

Studies like the one we present here are based on historical data recorded over a long period. It is important to stress that data management is an obscure task that normally receives little attention because managers and scientists do not obtain career rewards from doing this. Likewise, little effort has been devoted to adequate analysis of historical management data. As Lindenmayer \& Franklin (2002) state, this situation leads to a loss of long-term environmental and managerial information, weakening both forestry research and practice.

Analysis of variance using repeated measurements makes it possible to group the forests and compare their measurements for each of the variables to evaluate. For the three groups of forests studied, they display a distribution between similar measurements and change curves both in merchantable feet and in standing volume that all resemble one another. All the groups begin at very low levels and reach a maximum level in the same period (the decade of the fifties) until stabilizing. In accordance with the results for the three forest groups, they display a high significance compared to the variability among and within the forests. We can also observe that there is greater significance after every second revision, showing that the effects of forest plan prescriptions are not found until two regeneration periods have taken place (40 years in this case).

There are a limited number of long-term studies focused on management plan impact over more than 50 years. The limited span of these studies is due to the difficulty in obtaining long-term, reliable, and comparable data sets. Charnley et al. (2008), examining the effects of the Northwest forest plan on the well-being of local communities, used a 30-year span (from 1979 to 2003).

\section{Conclusions}

It is important to stress the fact that traditional organization methods are valid tools for managing forests, as reflected by their benefits in making ongoing usage and improvement of forest stands compatible. It is important to implement organizations and their revisions in a sustained manner over time, for at least the medium term (40 years or more), because time is needed to obtain full responses to management prescriptions. Many concerns regarding susceptibility and vulnerability to global change of different forest values (timber, recreational, biodiversity, and so on) have been related to management practices. Further research is needed to understand the complex, long-term impact of forest management fully.

\section{Acknowledgements}

This paper has been made possible through different research projects financed by the Spanish Research Ministry (project codes AGL-2001-1780, AGL2004-07094-C02-02, and AGL2007-65795-C02-01). L.F. Osorio acknowledges support from the AECID (Agencia Española de Cooperación Internacional y Desarrollo).

\section{References}

Bravo F, Bravo-Oviedo A, Díaz-Balteiro L (2008). Carbon sequestration in Spanish Mediterranean forests under two management alternatives: a modelling approach. European Journal of Forest Research 127 (3): 225-234. - doi: 10.1007/s10342-007-0198-y

Bravo-Oviedo A, Sterba H, del Río M, Bravo F (2006). Competition-induced mortality for Mediterranean Pinus pinaster Ait. and P. sylvestris L. Forest Ecology and Management 222: 88-98. doi: 10.1016/j.foreco.2005.10.016

Bravo-Oviedo A, del Río M, Montero G (2007). Geographic variation and parameter assessment in generalized algebraic difference site index modeling. Forest Ecology and Management 247 (1-3): 107-119. - doi: 10.1016/j.foreco. 2007.04.034

Charnley S, Donogue EM, Moseley C (2008). Forest management policy and community wellbeing in the Pacific Northewett. Journal of Forestry 106 (8): 440-447. [online] URL: http://www.ingentaconnect.com/content/saf/jof/2 008/00000106/00000008/art00011

Davis LS, Johnson KN, Bettinger PS, Howard TE (2001). Forest management: to sustain ecological, economic and social values. McGraw-Hill, New York, USA.

Davis CA (2002). Statistical methods for the analysis of repeated measurements. Springer-Verlag, Berlin, Germany, pp. 415.

De-Lucas AI, Robledo-Arnuncio JJ, Hidalgo E, González-Martínez SC (2008). Mating system and pollen gene flow in Mediterranean maritime pine. Heredity 100: 390-399. - doi: 10.1038/sj.hdy.6801090

De-Lucas AI, González Martínez SC, Hidalgo E, Bravo F, Heuertz M (2009). Admixture, one- source colonization or long-term persistence of maritime pine in the Castilian Plateau? Insights from nuclear microsatellite markers. Investigación Agraria: Sistemas y Recursos Forestales 18 (1): 3-12. [online] URL: http://www.inia.es/ gcontrec/pub/003-012_Admixture

1238675152312.pdf

González-Martínez SC, Salvador L, Agúndez D, Alía R, Gil L (2001). Geographical variation of gene diversity of Pinus pinaster Ait. in the Iberian Peninsula. In: "Genetic response of forest systems to changing environmental conditions" (Müller-Starck $\mathrm{G}$ et al eds). Kluwer Academic Publishers, Dordrecht, Boston, London, pp. 161171. [online] URL: http://www.plantevol.arrakis.es/pdf/Gonzalez-Martinez et al 2001 BOOK.pdf

Hair JF, Black WC, Babin BJ, Anderson RE, Tatham RL (2006). Multivariate data analysis. Pearson Prentice Hall, Upper Saddle River, NY, USA.

Herrero C, San Martín R, Bravo F (2007). Effect of heat and ash treatments on germination of Pinus pinaster and Cistus laurifolius. Journal of Arid Environments 70: 540-548. - doi: 10.1016/j.jaridenv.2006.12.027

Lindenmayer DB, Franklin JF (2002). Conserving forest biodiversity. A comprehensive multiscaled approach. Island Press, pp. 351.

Pascual D, Maguire DA, Bravo F (2007). Assessing the applicability of growth models to new species and regions: an example comparing Mediterranean maritime pine in central Spain to Ponderosa pine in Southwestern Oregon, USA. Western Journal of Applied Forestry 22 (4): 269277. [online] URL: http://www.ingentaconnect.com/content/saf/wjaf/2007/00000022/00000004/ $\operatorname{art00006}$

Quinn JP, Keough MJ (2002). Experimental design and data analysis for biologist. Cambridge University Press, Cambridge, UK, pp. 537.

Ribeiro MM, Plomion C, Petit R, Vendramin, GG, Szmidt AE (2001). Variation in chloroplast single-sequence repeats in Portuguese maritime pine (Pinus pinaster Ait.). Theoretical and Applied Genetics 102: 97-103. - doi: $10.1007 / \mathrm{s} 001220051623$

Statsoft INC (1995). Statistica for Windows (computer program manual). Stat soft inc., Tulsa, OK, USA.

SAS Institute (2006). SAS/STATTM User's Guide, Relase 9.1. Cary, NC, USA.

Vendramin GG, Anzidei M, Madaghiele A, Bucci G (1998). Distribution of genetic diversity in Pinus pinaster Ait. as revealed by chloroplast microsatellites. Theoretical and Applied Genetics 97: 456-463. - doi: 10.1007/s001220050917 